\title{
関係構造による高齢者コミュニ SPACES COMPOSITION OF THE ティの空間構成の研究 \\ ELDERLY COMMUNITY BASED ON STRUCTURES OF HUMAN RELATIONS WITH OTHERS
}

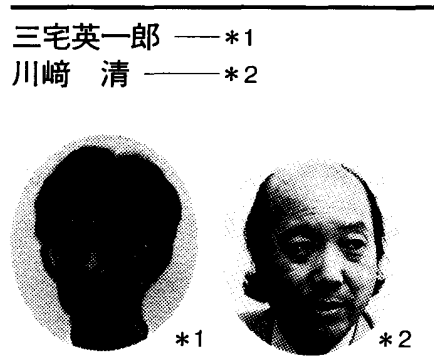

\section{Eilichiro MIYAKE \\ Kiyosi KAWASAKI}

Elderly community spaces and their care places for people are spaces where human beings live. They are not functional spaces where are intended for adaptability for the purposes but general living spaces. Introducing two method concepts which one is to analyzes dialectically relationship between an human action and a space which is mediated by structures of human relation with others, the other is a typical space concepts that compose the whole space and its elements, this paper systematizes the order of living functions of elderly community spaces and organizes their spaces composition as the general living spaces for human beings.
キーワード

個人存在としての関係性, 性または家族としての関係性, 共同社会の成員とし ての関係性, 行動と空間の弁証法, 機能の発見, 背景空間
Keywords :

Human relation as being individuality, Human relation as being gender or a family, Human relation as being social coexistence, Dialectic of an action and a space, Finding functions, Back ground spaces

\section{まえがき}

高齡者のコミュニティ空間の生活機能の分析と体系化の既往の研 究き1は は、高齢者の居住施設を目的機能空間と概念化した上で、老 人の行動とさまざまな物的施設と人的サービスとを、二つの外在的 な要素として捉え、要素相互の適応性の分析を目的として行われて きている。しかし、高齢者の介護の場は人間存在の空間であり、目 的機能空間ではなく、普遍的な生活空間であると考えられる。

本稿では人間の他者に対する関係性の構造を媒介として、人間的 行動と空間の関係を弁証法的に分析する方法概念 ") と全体と部分を 構成する典型空間の空間概念を導入して、普遍的な生活空間として の高齢者のコミュニティ空間の生活機能の秩序の体系化と空間構成 の研究を設計事例の経験を通じて試みている。その方法概念と分析 結果を以下に報告する。

\section{1. 関係構造による行動と空間の分析}

私たちの生活慣習と同時に、文化としての人間関係の、社会にお ける現実について、ジョン・レックズは、次のように記述してい る。「五歳の子供の世界をご覧なさい。親子関係、近隣関係、言語 社会、同じ宗教を持つひとたちとの関係、死者、先祖、地域社会の 源流についての話。こういったものに聿まれて、人は立ち現われて くる。だれも純粋な個人では有り得ない。人間であるとはそういっ たくもろもろのきずな〉を含んている。」〈もろもろのきずな〉と は、ここでは、人間の関係性の体系すなわち関係構造と読まれるべ
きであり、人間の行動と知覚が最初に向けられるのは、他者の行為 を対象とするのであって、自然的対象に向けられるのはより高度な 意識に属している。人間の行動と知覚にとっては人間的意味の方が 感覚記号よりも先に与えられているのである。

人間の行動之空間の知覚が他者への人間関係によって構造化され ている身体的現実を、メルロ・ポンティは次のような意味として表 現している。「人間の初発段階の知覚は、他者の存在につきま之わ れて、他者の行為とその対象物に向けられており、自然的諸物一般 に対する知覚は成人するにしたがって志向される。」3)人間の意識 の他者に対する関係性のシステムを関係構造と定義してそのシステ ム分析を試みることにする。この関係構造は意識の存在形式の働き のことであり、高齢者を含む人間存在に普遍されているのである。

\section{(1 - 1$)$ 関係構造の第一の次元・D人の関係性}

基本的な実在であり、関係構造の第一の次元の在り方は、〈自由 な〉個人としての人間、個人存在の形式としての関係性である。

私ひとりが、身体の運動と表現を媒介として、私を取り囲む全て の他者及び自然的諸物と結ぶ、直接的な関係の諸相の在り方であ る。個としての存在として自由に思考し、意欲し、行動することを 願い、自己充足のために生きている。人間は、実りの果てに枯れる 植物が残してくれる実をまた地中に埋めることによって再び同じ植 物が生成することを自覚したとき、自然の中に生成して流れる時間 の意味を意識したと思われる。個としての人間として、子が育ち、 老死を迎え、人間もまた自然と同じように、時間の生成に従うこと

*1 Assoc. Prof., Civil and Environmental Systems Engineering, Biwako Kusatu Campus, Ritumeikan University, M. Eng.

(玄 525 草津市野路東 1-1-1)

2 立命館大学理工学部環境システム工学科 教授・工博
*2 Prof., Civil and Environmental Systems Engineering, Biwako Kusatu Campus, Ritumeikan University, Dr. Eng. 
を意識したであろう。個人存在としての私たちの生の諸相は自然的 時間性に従っており、生命代謝的、思考的、感覚的な知覚意識がそ の基礎を構成している。

\section{$(1-2)$ 関係構造の第二の次元・二人の関係性}

関係構造の第二の次元の在り方は、私たちが性としての人間とし て固有二人の男または女として結ぶ関係性てある。それは個人とし て独立した人間関係ではなく、二人の個的な生による相互関係性で ある。これは家族の関係性亡呼ばれ、人間は男か女として、夫婦と か、親子とか、兄弟姉妹とか、親族とかよばれる人間関係の構造の なかにおかれる。女性が子を妊娠し、分婏し、男性の分担も加えて 育て、成人させるという〈二人の関係性〉の時間性は自然の時間性 とは異なった意識として自覚され、自然の時間性を基底とした、 脱・自然的時間性亡言うことができる。それは、〈自分の現実を他 者のうちに持っている〉恋人、友人、などく二人の関係性>におい て相互に依存している人間関係へ拗がり、覆っている。

この〈二人の関係性〉は、情念という持続する感情を基礎として いる。二人の、愛しあう、または、憎しみあう関係の在り方は、

〈二人の関係性〉のみが作りだし、その外部にある他者や自然的世 界を排除して閉鎖しており、独自の意識的領域であるプライバシー の空間を構成している。

$(1-3)$ 関係構造の第三の次元・三人の関係性

人間の関係構造の第三の次元は、三人の関係性である。すなわ

ち、 $\mathrm{A} \cdot \mathrm{B}$ の二者関係がCを排除せず、 $\mathrm{A} \cdot \mathrm{C}, \mathrm{B} \cdot \mathrm{C}$ の二者関係 か、それぞれ $\mathrm{B} ， \mathrm{~A}$ を排除しないという、三つの条件が同時に成立 することを前提とする関係構造である。三者関係が確立している場 においては、三者以上においてもこの関係構造が論理的に成立す る。これは人々の中で各個人が役割を持つ自己表現が行われている 人間関係のシステムである。すなわち、それぞれの個人の身体の自 己表現の交換が成立し、各関係性が等距離である関係システムであ り、共同社会関係の空間である。三人の関係性〉としての関係構 造というものは、〈自然〉の贈り物の形で、人間に与えられる社会 の形態ではなく、人間が骨折って作り上げてゆかねばならないもの であり、真の意味ての創造行為 (’゙ある。それは、自然の時間性に よって生成されるのではなく、人間の知的想像力という反・自然的 時間性によって生まれる。

共同社会の成員亡しての人間の存在形式の次元の始まりの神秘に ついて、オルテガ・イ・ガセットは、ギリシャ・ローマの都市共同 体ポリス・ウルブスの発生を次のように記述している。

「原野の一部を壁で井み、無定形で無限の空間に対して、閉鎖さ れた有限の空間を作ればよいのだ。こうして広場ができあがる。広 場は、家のように原野に存在する内部空間ではなく、まさに、原野 の否定そのものである。…無限の原野から分離し、原野に対して身 を構える、この小さな反逆的な原野は言わば廃止された原野であ り、従ってそれは、全く新しい空間であり、その中で人間は、植物 や動物とのあらゆる結び付きから自己を解放し、純粋に人間的な別 世界を創造したのである。

人間存在の形式の第三の次元の $<$ 三の関係性 $>$ は、超・個人の 存在形式であり、同時に超・家族としての存在形式の関係構造であ る。

$(1-4)$ 高齡者のコミュニティ空間における関係構造の体系
私たちが、この世界に生きること、すなわち、生活環境において 知覚し、行動することは、自己と他者に対する関係構造の生成と発 見である。関係構造の三つの次元は、私たち一人一人にとって、時 間的および空間的に独立して生きられているのであり、その関係構 造の次元のどれもが、欠落したり、他の二つに従属したりしてはな らない。このことは私たちの存在の形式には、三つの独立した次元 の位相があり、生活環境の意味の三つの基本となる秩序を構成して いることを意味している。私たちは、関係構造の第一の次元であ る、自由な個人としての自由意思が尊重され、第二の次元の、性と しての人間から生まれる愛が満たされ、第三の次元の、共同社会の 成員としての公正が行使されることによって、人間存在の形式を生 きているのである。

2. 行動と空間の弁証法による高軨者コミュニティの生活機能の発 見亡関係構造による秩序分析の方法概念

(2－1）行動と空間の弁証法による高齢者コミュニティの生活機 能の発見

空間の計画行為は、他者の行動への共感亡願望の可能性亡して存 在するのであって、例えば、私たちは空間の中に、人々が〈何か座 れそうな物〉を作り、行動と空間の弁証法的な関係 ${ }^{1)}$ にって人々 がそれを発見し、そこに座るであろうことを共感とともに願望する 行為である。人々を機械的に座らせるために椅子を作るのではな い。行動之空間の関係が機械的ではなく弁証法的なのである。生活 機能の発見の構造とは、行動と空間の弁証法であり、また同時に、 座るという機能の発見と行動が、自分自身の一人の行為であれ、他 者と一緒に座るのであれ、〈自己一他者〉の関係構造の新しい態度 がそこに創造され、開示されているのである。

機能という生活空間の意味が、アプリオリに客観的理念として存 在して、それに適応するように機械的に即物化された空間の中で、 人間の行動が一義的に行われるのではない。人間の関係構造によっ て発見される高跉者のコミュニティの生活機能は、人間的行動と空 間の構造の意味の創出という主体的な生活機能の発見行為となるの であるく眠りたくなるような場所〉、く働きたくなるような場所 >、《何か食べたくなるような場所〉、《病気や不安を癒して貫え そうな場所 $>$ 等、行動と空間の弁証法によって機能を発見して貫え そうな場所の関係性のシステムの総体が高齢者コミュニティの生活 機能である。

建築家は設計行為における想像のコミュニティ空間を自分自身の 身体で生き、運動し、そこに住み込めば発見し、経験し、現前する であろうと思われる精神状態や行動状態を言葉で探し、それを弁証 法的関係において空間に重ね合わせて、人間の行動を、身体の運動 と表現感覚による空間の開示として表現するのである。

\section{$(2-2)$ 関係構造による空間の秩序}

同じ空間にいるものは、同じ関係性を生きている。高齢者のコ ミュニティの空間においては、高齢者および職員の空間も、共にコ ミュニティの空間を生きている関係構造の空間として、理解されな ければならない。従って、高齢者と職員の行動を受益者と奉仕者と して、目的論的に分類して、機能主義的目的行動に還元すること は、本稿の論述では行わない。たとえ社会制度上の職業として遂行 されるとしても、人間の関係構造における行動の本質は、その行動 
表一 1 高龄者コミュニティ空間の関係構造による生活機能の構成

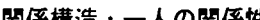

一人の関係性における人々か、空間で発見して欲しい、計画者から他者への志向性としての生活機能

\begin{tabular}{|c|c|c|}
\hline $\begin{array}{l}\text { 生活機能の発見 } \\
\text { 知覚と意味 }\end{array}$ & $\begin{array}{l}\text { 行動 } \\
\text { 精神状熊と行動状悲 }\end{array}$ & $\begin{array}{l}\text { 空間 } \\
\text { 施設・環境 } \\
\end{array}$ \\
\hline 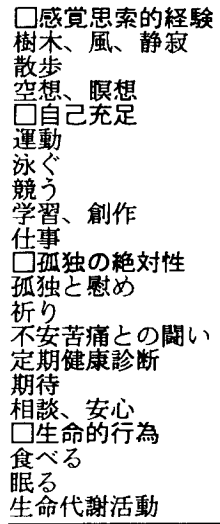 & 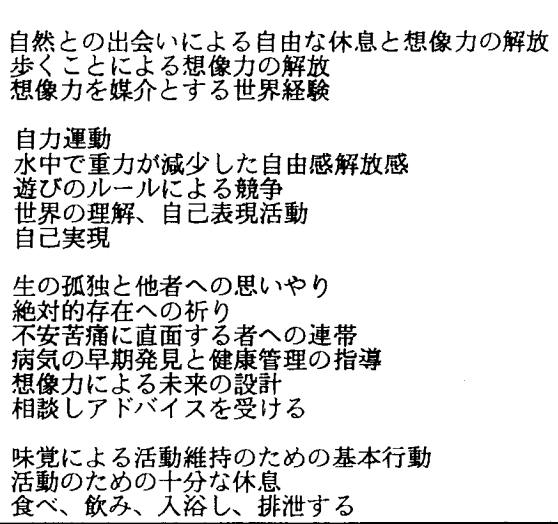 & 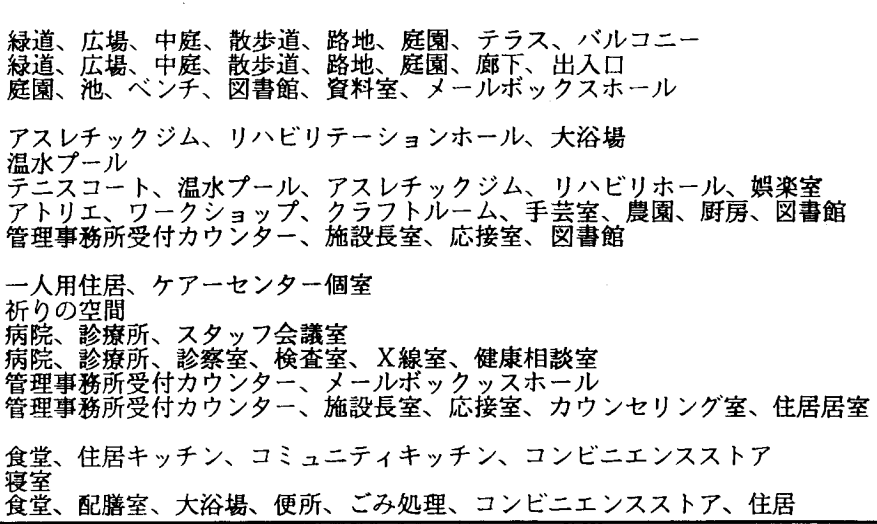 \\
\hline
\end{tabular}

閶係構造 ·二人の関係性

二人の関係性における人々が、空間で発見して哯しい、計画者から他者への志向性としての生活機能

\begin{tabular}{|c|c|c|}
\hline $\begin{array}{l}\text { 生活栱能の発見 } \\
\text { 知賞亡意味 }\end{array}$ & $\begin{array}{l}\text { 行動 } \\
\text { 精神状態亡行動状態 }\end{array}$ & $\begin{array}{l}\text { 空間 } \\
\text { 施設・環境 }\end{array}$ \\
\hline 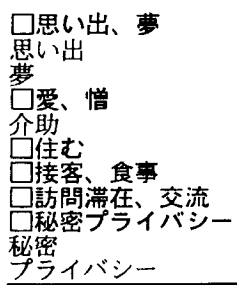 & 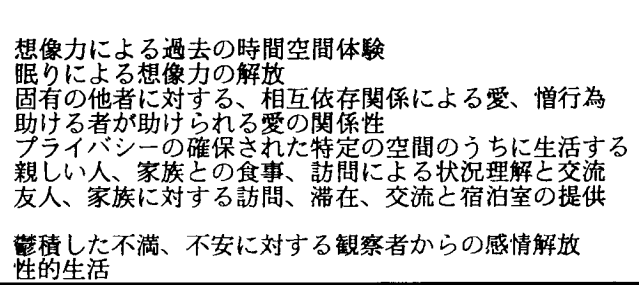 & 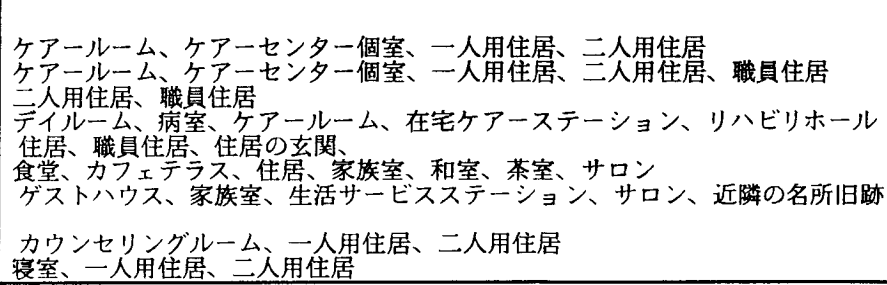 \\
\hline
\end{tabular}

咸係構造・三人の夙係性

三人の関係性における人々が、空間で発見して欲しい、計画者から他者への志向性としての生活機能

\begin{tabular}{|c|c|c|}
\hline $\begin{array}{l}\text { 生活機能の発見 } \\
\text { 知覚亡意味 }\end{array}$ & $\begin{array}{l}\text { 行動 } \\
\text { 精神状態亡行動状態 }\end{array}$ & $\begin{array}{l}\text { 空間 } \\
\text { 施設・環境 }\end{array}$ \\
\hline 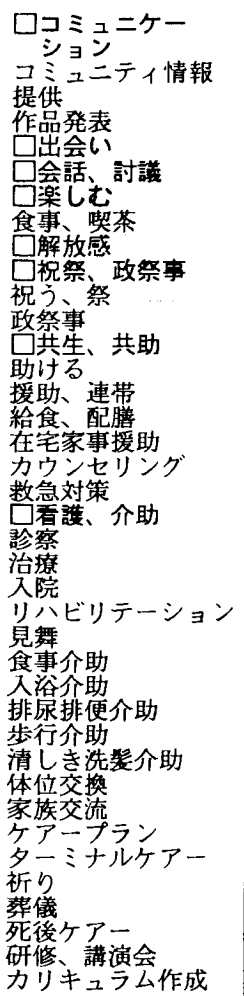 & 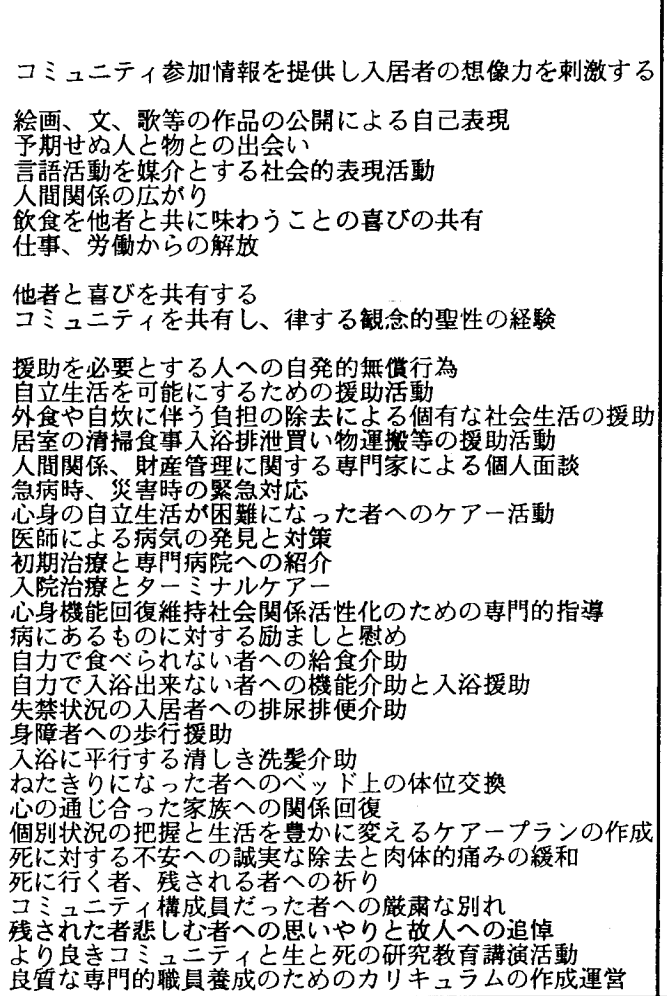 & 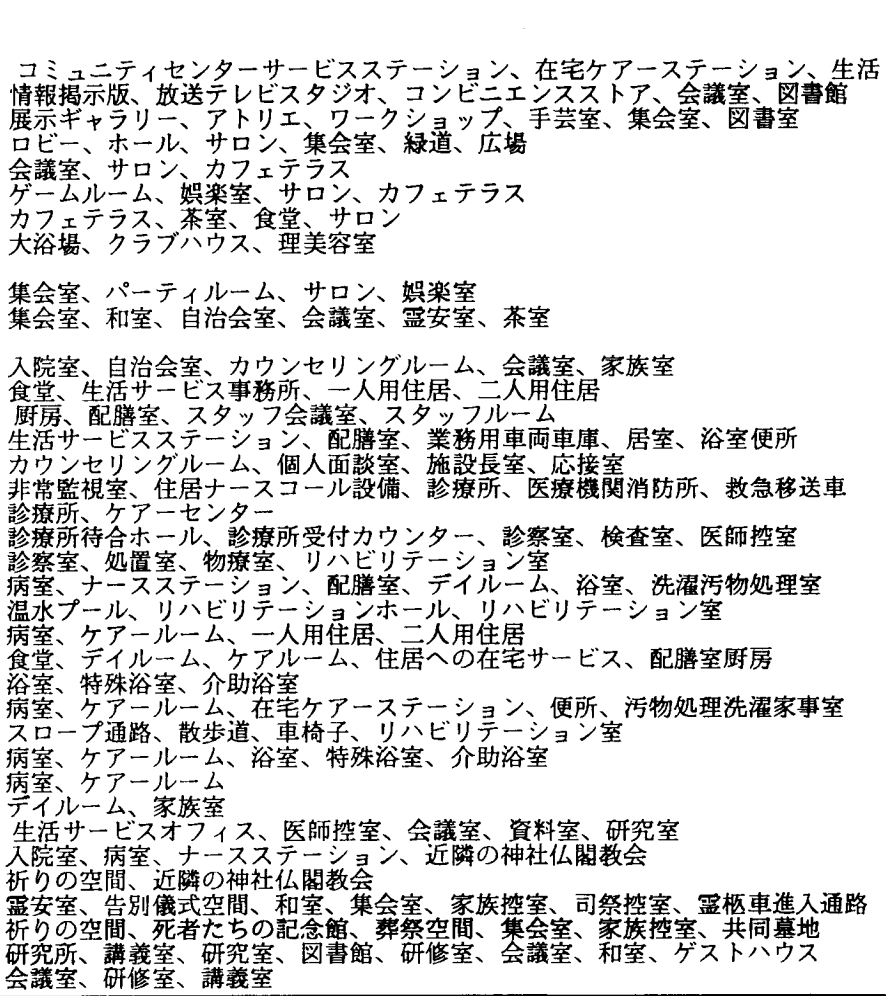 \\
\hline
\end{tabular}


の意味である。従って、一つの同じ空間に生きる人々は、共通の関 係性を生きており、他者に対して、共通の態度と感性の関係を生き るのである。

\section{3. 高齢者コミュニティ空間の生活機能の構成}

空間構成の計画事例であるこの高秢者コミュニティ空間の施設計 画は、事業者によって<佐倉ゆうゆうの里 >と命名され、高齢者コ ミュニティ・マスタープラン委員会が事業者を議長として 8 名の建 築家を委員として計画された ${ }^{6)}$ 。マスタープラン委員会は、198 4 年 4 月から同年 12 月まで、月に 1 回計 9 回にわたり開催され た。このプロセスを経過して発見される生活機能を、私たちは関係 構造のシステムによって序列化を行い、それらの機能相互の親和性 によって類型化を行った。この計画事例における高龄者コミュニテ 1の生活機能の分析と構成は次のように記述される。

\section{( $3-1)$ 一人の関係性の空間の生活機能}

想像空間のコミュニティにおいて、私たちが発見する、生活機能 の第一の秩序を構成するのは、個的な存在としての人間である私一 人が、全ての他者と自然的な諸物に開いて共に在り、行動する風景 である。この関係性の空間では、まず、<生命代謝活動>があり、 食べる、飲む、眠る等の類型化された機能が発見される。さらに、 この関係性の特質は＜感覚的思索的>であり、また、意欲し、行動 して、く自己充足>を目指す生活機能が発見される。私と他者と は、自由と孤独の関係性において全く等しい存在であり、全ての他 者や自然に開いており、それらの存在への共感として関係づけられ ている。その意味で、この関係性の空間で発見される機能は、く孤 独でしかも絶対的>であり、それは原宗教的空間の機能として発見 される。以上の一人の関係性の空間における発見される生活機能を 類型としてまとめ、（表一-1）に、関係構造一人の関係性の生活機 能の発見として示している。

\section{( $3-2)$ 二人の関係性の空間の生活機能}

建築家か、見い出す生活機能の第二の秩序は、「私たち二人」の 相互依存の関係構造における私が空間に見い出す生活機能であり、 一組の男女によって作られる家族の関係性の空間の生活機能であ る。

この関係性によって最初に発見される生活機能は、プライバシー の伴った家族のく住まい>である。またその対幻想の<思い出、夢 >である。さらに、その幻想の基底である、<爱 >であり<憎悪 $>$ である。また、時には、親しい人を＼cjkstart接客し食事をし>、く訪問 し、滞在する>生活機能が発見されるはずである。また、自己のく プライバシーの秘密＞を打ち明けることも、この関係性の生活機能 の特質でる。二人の関係性において発見される、以上の生活機能 を類型として、分類してま亡め、関係構造二人の関係性の生活機能 の発見として (表一1) に示した。

\section{( $3-3)$ 三人の関係性の空間の生活機能}

想像空間の中で発見する第三の秩序の生活機能は社会的活動行為 の在り方でるるここで発見される社会生活機能は、三者関係を同 時に成立させる知的創造活動が媒介しているのが明らかであり、そ の意味において、コミュニティ空間の計画者てある建築家も、想像 のコミュニティ空間を構成する第三者という意味において、三人の 関係構造の生活機能に限定すれば、将来の居住者と質的に等価な生 活者としての存在理由を持っていることになる。

このような三人の関係性の空間概念の分析により、私たちは高龄 者と職員とが、共に働き、共に生き、心身において看護し合う、社 会的場において、発見する機能をくコミュニケーション>、<出会

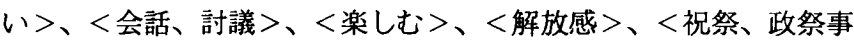
$>$ 、<看護、介助 >の類型亡してまとめ、関係棈造の三人の関係性 の生活機能として（表一1）に示した。

\section{4. 行為の背景空間と生活機能}

\section{(4-1) 典型空間と数地の分節}

関係構造のシステムによる空間想像から、個々に各々独立的に発 見されてくる生活機能というものが、生活空間という全体性の内て 相互に適切な位置を与えられるためには、空間之機能を結び付け、 全体性亡部分を結び付ける媒介的な空間構造の概念が必要でる。

私たちが行動するのは、行動とは何の関係もない空虚な空間のな かでではなく、行動との間に十分に規定された関係を持っている背 景空間》においてである゙。この背景空間において行動と空間の弁 証法によって発見される生活機能とその背景空間は結び付くのであ る。行動と空間の弁証法によって発見される生活機能は、関係性の 場亡いう全体の中の「ここ」から「かしこ」へと方向づけられた行

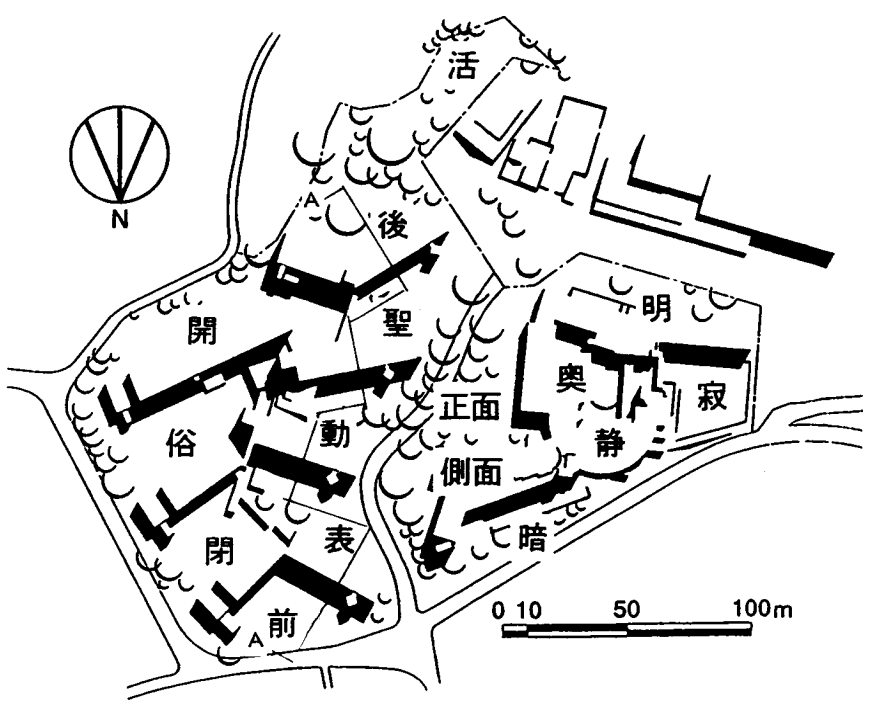

図ー1 典型空間による敷地空間の分節とマスタープラン

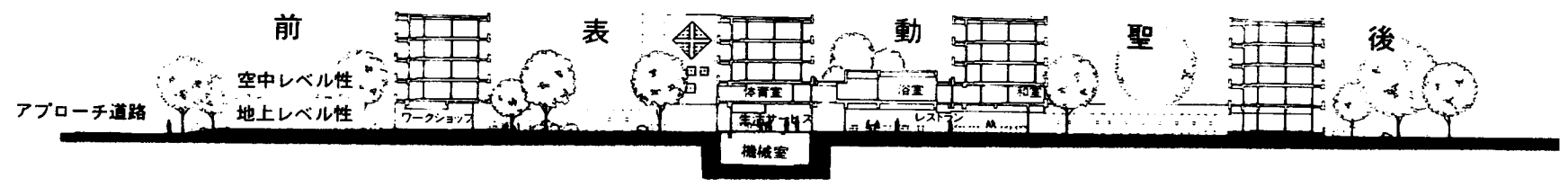

図ー2＼cjkstart典型空間領域の地上レベル性と空中レベル性

（數地東側南北方向縦断 $<A-A>$ 断面図） 縮尺 $1 / 1200$ 
表一 2 典型空間を媒介とする関係構造による生活機能空間の全体配置構成

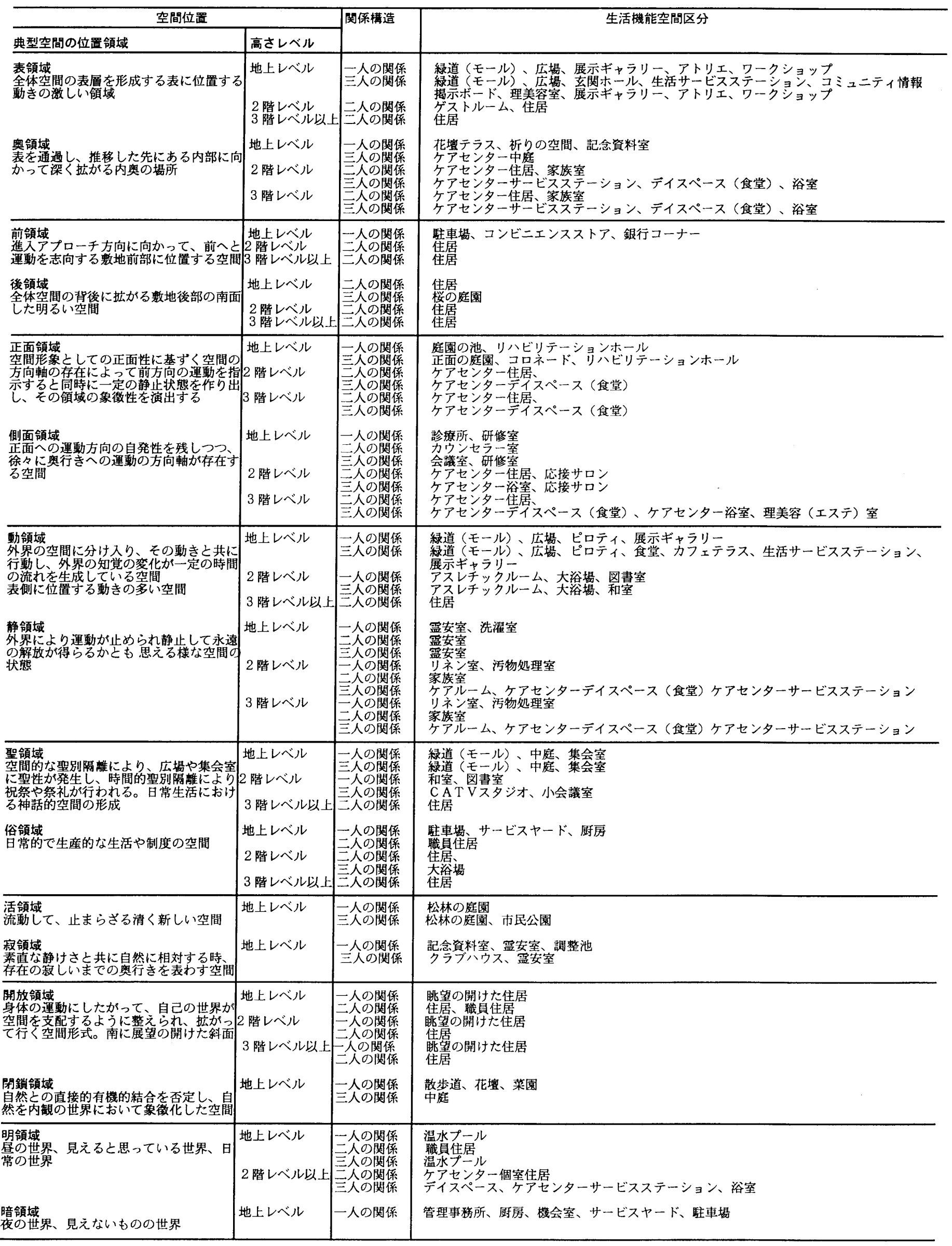


㠺の、塄体的で明確な背景を持った場所で発見されている。

それは行動の背景空間として空間の具体的質量と領域によって類 型化された空間表情により構成されている空間である。

行動と空間の弁証法における私たちの身体は、そのつどの空間質 量上配置の表情によって、空間構造の体制化を行い、行動の背景空 間として全体空間から切り離しえない部分として、仮設的に「こ こ」という場所を、「かしこ」の場所へと方向づけられた対になっ た空間構造とともに発見している。「ここ」という場所は、常に

「かしこ」の場所との対的で相対的な関係における「ここ」の選択 であり、また「かしこ」も「ここ」との対的な相対性における「か しこ」の生成である。行動の背景空間である「ここ」という場所は 「ここ」から「かしこ」への方向性を持ち、同時に対的空間構造を 形成している。

それは空間構成の過程においては、想像的空間における空間の質 量之配置構成の試行錯誤の行為の過程を経て、行動と空間の弁証法 を媒介とする、身体のスケールと運動能力および表現能力による、 自然的世界の仮設的な人間化の作業である。

この行動との間に十分に規定された関係を持ち、行動の背景空間 としての具体的質と領域を構成している方向性と対的な空間構造を 持つ背景空間を仮説として典型空間と定義する。

これによりここで記述されている空間構成の事例においてはく表 と奥 $>$ 、 $<$ 前と後 $>$ 、 $<$ 正面と側面 $>$ 、 $<$ 動亡静 $>$ 、 $<$ 聖と俗 $>$ 、

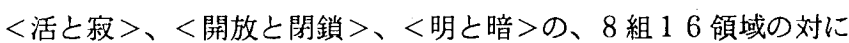
なった典型空間のシステムを選択し、マスタープランにおける敷地 空間の質量と配置の分節構成を行っている。マスタープランとは、 全体亡部分の空間の関係性においてそれらの明確な外在的空間領域 の構成を確定すること、すなわち敷地空間を分節することである。 この敷地空間の分節構成が、<典型空間>の空間概念の外在的領域 化である。行動亡空間の弁証法という空間構造の本質的な弁証法的 仮設性に基づく典型空間のシステムは空間構成において、想像的に 「ここ」で生成されている空間の類型化された表情の固有性を表現 しており、それは弁証法的な仮設性を本質的な構造としている。 従ってここで選択されている 8 組 16 領域の典型空間のシステム は、空間構成の方法概念において、想像空間における弁証法的仮設 性の空間諭理としてのみ存在意味を有しているのであり、一般普遍 的な存在としての空間を意味しているのではない。このようにして 仮設的に領域化された典型空間を具体的な空間表情の質の概念的記 述とともに、(図一-1）及び（表一2）としてまとめている。

$(4-2)$ 典型空間による機能分析

建築家よる願望として、探し求められた生活諸機能が、新しく創 造されてくる空間のなかで、現実に発見され、定着するかは、実証 的には確かなことではない。しかし、想像空間のうちで、運動し、 考え、発見した時の、その背景架間の表情というものが、的確に現 実化されることが可能であれば、そこに住む人々が、その空間のう ちで、建築家と同じ様な機能を発見し、それを引き出すことは、大 いに有り得ることである。したがって、特定の生活機能は、あくま でも、全体空間の中で、最も似つかわしい場所におかれる必要があ る。この全体と部分を結び付け、空間と機能を結び付ける媒介的な 空間構造の概念が典型空間である。敷地空間の外在的領域のスケー ルを確定し分節した、表情と方向を持つ 8 組の仮説的に選択された
典型空間、すなおち、<表と奥 $>$ 、 $<$ 前と後 $>$ 、 $<$ 正面と側面 $>$ 、 $<$ 動と静 $>$ 、 <聖と俗 $>$ 、 <活と叔 $>$ 、 <開放と閉鎖 $>$ 、 $<$ 明亡暗 $>と い う$ 行動の背景空間の領域に、関係構造によって序列化され、 行動と空間の弁証法によって発見された生活機能を重ね合わせて行 くのである。

典型空間によって分節された空間は、空間の拡がりの領域の確定 であり、それは地上レベルという大地の感覚と直結した空間性と、 地上から浮上した、2 階以上の空中レベルの空間性と言う、空間の 位置のレベルの高さによって、空間断面的二つの空間性に分けられ る壮。(図一2)

地上レベルの空間性は、自然的世界の現実感覚が強く支配する聓 間構造の特性を持ち、空中レベルの空間性においては、現実世界 に、距離を取りながら、行動亡空間の客観化や、思索化、抽象化が 空間の志向性として現われる空間特性を持つ。

したがって、各生活機能の空間の位置を設定するに際しては、典 型空間に上る領域化の内部において、地上性亡空中性という、その 高さレベルの空間断面の位置も各機能にふさわしく設定される必要 がある。このようにして、典型空間の概念によって、分節された敷 地空間の領域（図一-1）に、ふさわしい生活機能（表一1）を分類 分析し、各機能の位置を定めて行き、各生活機能の全体空間におけ る配置構成を（表一2）として作成した。

\section{結び}

本稿の設計行為が目指すところは、目的手段系のシステムとして 目的機能への適応性を秩序とする空間を構成するのではなく、身体 による行動之空間の弁証法によって、全体空間が状況に応じて意味 を涌出する空間構造を生み出すことにある。ここに現実に設営され ている高齢者コミュニティ空間は過去 9 年間にわたり現在までそこ に住む生活者の知恵と情熱と労働によって、さらに調整され、再構 成され続けられている。今後は、この新しい生活者により発見創造 されている空間の意味の実証的分析を通じて、設計方法概念の現実 性の内実を分析し、生活空間の構成方法概念を茾証法的にさらに内 実化させていくことが必要と考えられる。

注 注1)この論述に関しては、下記の既往研究諭文を貴重な参考とさせて頂い た。諭文タイトルを列記し、謝辞にかえさせて頂く。 石田敏他：終生の場に関守方考察、日本建築学会計画系諭文集、 no.477,pp91-100,1995

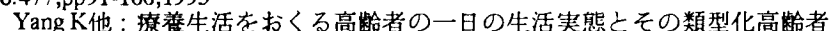
の療童環境の適正化に関する研究、日本建筑学会計画系論文集、no.466,pp3746,1994 注2)ケグィン・リンチは著書「都市のイメージ（丹下健三他訳、岩波書店

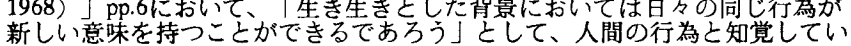

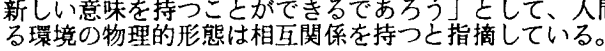

注3) テンマークの建築家 J・ゲールはその著書「屋外空間の生活とデザイ (北原理雄訳、鹿島出版会、1990)」pp.122において地上レヴェルと2 階 以上のレウェルとのコミュニケーションの可能性を実証的実験により報告し ている。

参努文献

1）三宅英一郎、川崎清、增池正和：関係構造による生活機能分析のための 方法概念 $の$ 基碳的研究、日本建築学会計画系諭文集第492号1997 年 2 月pp241-247

2) 浔ン・レックス ( J o h n R e x ) : 民族粉争と多元文化、朝日新 聞、1995. 9.24 、朝刊 13 版

3) メルロ・ポンティ: 行動の構造、みすず書房、1969、pp. 247

4 ) オルテガ・イ・ガセッ卡: 大衆の反逆、白水社、1984,pp208

6) 主宅英一郎：共存の空間、新建築、198808,pp.267

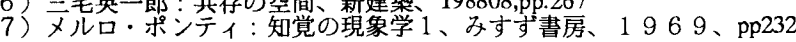

[1997年 6 月 6 日原稿受理 1997 年 9 月 1 日採用決定］ 